\title{
Trace Elements Concentrations and Human Health Risk Evaluation for Four Common Fish Species in Sinop Coasts (Black Sea)
}

\author{
Ayşe Gundoğdu',a,*, Saniye Türk Çulha ${ }^{2, b}$, Fatma Koçbaş̧,c \\ ${ }^{1}$ Fisheries Faculty, Sinop University, 57000 Akliman Sinop, Turkey \\ ${ }^{2}$ Fisheries Faculty, Izmir Katip Celebi University, 35620 Cigli/Izmir, Turkey \\ ${ }^{3}$ Faculty of Arts and Sciences, Celal Bayar University, 45140 Muradiye/Manisa, Turkey \\ *Corresponding author \\ A R T I C L I N F O A B S T R A C T \\ Research Article \\ In the study, Trachurus trachurus, Engraulis encrasicolus, Merlangius merlangius euxinus, and \\ Mullus barbatus from along the coast of Sinop were analysed for the content of copper $(\mathrm{Cu}), \mathrm{zinc}$ \\ $(\mathrm{Zn})$, lead $(\mathrm{Pb})$, cadmium $(\mathrm{Cd})$, iron $(\mathrm{Fe})$, nickel $(\mathrm{Ni})$ and aluminium $(\mathrm{Al})$ in the muscle. $\mathrm{Zn}, \mathrm{Pb}$ and \\ $\mathrm{Cd}$ concentrations were determined to be lightly higher than the acceptable rates in fish samples. \\ Received : 30/03/2020 \\ Accepted : 26/08/2020 \\ The provisional tolerable daily and weekly intake of trace metals in our work were all under than \\ the limits set by the Food and Agriculture Organization/World Health Organization, while for Cd, \\ only $M$. barbatus was higher than FAO limits. E. encrasicolus and M. barbatus had the highest \\ values for the collected total target danger section, but they did not posture a potential hazard within \\ the diet of local residents. For carcinogenic and non carcinogenic risk assessment, the results were \\ lower than the admissible rate of EPA. In the four fish species in the work, the Target cancer risk \\ Keywords: \\ Fish \\ values of $\mathrm{Ni}$ were greater than $10^{-4}$, whereas the Target cancer risk values of $\mathrm{Pb}$ were smaller than \\ Metal pollution index \\ $10^{-6}$. According to these results, it is thought that the $\mathrm{Ni}$ concentration in fish does pose a \\ Permissible levels
} Target cancer risk Target hazard quotients

https://orcid.org/0000-0003-1323-1003 http://orcid.org/0000-0002-1053-3455
${ }^{\mathbf{b}} \otimes$ trksanye@gmail.com http://orcid.org/0000-0003-0380-0858

\section{Introduction}

Seafood and fish are an important source of nutrients for the World's growing population in terms of the protein and minerals (essential trace elements), essential fatty acids and specific vitamins. Furthermore, the n-3 fatty acids of polyunsaturated in fish are biologically significant and have been determined to be connected with a reduce risk of cardiovascular disease (Kromhout et al., 1985; Svensson et al., 1995; Han et al., 2000). Depending on the concentrations of trace elements, they can have helpful or deleterious influences on animals, plants and human life (Förstner and Wittmann, 1981). Some trace metals cause highly toxic effects even at very low concentrations in living tissues. For instance, metals taken with nutrition such as arsenic, mercury, lead and cadmium have caused harmful and toxic effects for human health (Stankovic et al., 2011; Stankovic and Jovic, 2012; Ateş et al., 2015). However, some metals only show toxic effects at very high concentrations, they are a natural component of the ecosystem due to their biological importance (Amundsen et al., 1997; Köse and Uysal, 2008; Tepe et al., 2008; Türkmen et al., 2008a; Türkmen et al., 2008b). When swallowed in large quantities, heavy metals are combine with the body's molecules such as enzymes and proteins, disrupting their functions and structures, and forming stable biotoxic compounds (Duruibe et al., 2007). Researchers have reported that fish and seafood caught in environments contaminated by heavy metals is a threat to healt when consumed by humans (Han et al., 1994; Sipahi et al., 2013; Mok et al., 2015; Javed and Usmani, 2016; Moslen and Miebaka, 2017; Bat et al., 2018). In recent years, researchers have concentrated on the question of whether trace metals are a risk to human health because of the consumption of fish and seafood (Abdallah, 2013; Ahmed et al., 2015; Yilmaz et al., 2016).

$90 \%$ of Turkey's annual production of approximately 500.000 tons of aquatic products is obtained through sea- 
fishing, while $75-80 \%$ of the production occurs in the Black Sea (TUIK, 2017). Due to its economic importance, the most commonly consumed target species off the coast of Sinop are pelagic and benthic species such as Trachurus trachurus (horse mackerel), Engraulis encrasicolus (anchovy), Merlangius merlangius euxinus and Mullus barbatus (red mullet). These fish are frequently consumed by humans due to the high quality of their meat quality and their taste. The aim of the work was to assess of the trace metal values in popular fish (red mullet, anchovy, horse mackerel and whiting) hunted in the coast of the Black Sea. The Potential health risks were also calculated for the trace metals as a result of consuming these fish. The health risk related to the trace metals in fish was assessed using Target Hazard Quotients (THQ) and the estimated purchases was compared with toxicological references. The total THQ (TTHQ) value was also calculated since there was a possibility of exposure to more than one chemical substance and this could increase the health risk. The study also appraised the carcinogenic and non-carcinogenic health risk to humans of fish consumption.

\section{Material and Method}

\section{Sampling and Analytical Method}

Samples of Trachurus trachurus; L.1758, Engraulis encrasicolus; L.1758, Merlangius merlangius euxinus; N. 1840 and Mullus barbatus; L. 1758 were collected from local salesman in Sinop between November 2008 and January 2009. Fish samples were preserved at $-21^{\circ} \mathrm{C}$ till the trace metals concentrations assessment. Total length $(\mathrm{cm})$ and weight $(\mathrm{g})$ of the fish were measured before starting the shredding process. The muscle tissue of all fish was disintegrated and dried after washing with tap water and pure water. They were weighed out and dried in the oven at $105^{\circ} \mathrm{C}$. Drying was continued till a permanent weight was achieved. The dried samples were then weighed and stored until analysis. The dried samples were homogenized as a fine powder using a stirrer and grinder, then weighed $0.5 \mathrm{~g}$ for analysis. Subsequently, the wet-burning method was performed by adding Hydrochloric acid $(37 \% \mathrm{HCl}$, Merck): Nitric asid $\left(65 \% \mathrm{HNO}_{3}\right.$, Merck) (3: 1) to the Teflon cups in a CEM MARS-5 microwave (Yap et al., 2004; Turk Culha et al., 2011). Values of copper (Cu), zinc $(\mathrm{Zn})$, lead $(\mathrm{Pb})$, cadmium $(\mathrm{Cd})$, iron $(\mathrm{Fe})$, nickel $(\mathrm{Ni})$ and aluminium (Al) were measured with ICP-AES spectrometry (Inductively Coupled Plasma-Atomic Emission Spectroscopy, Varian Liberty- Series II). Standard solutions were prepared from stock solutions (Merck, multi element standard). Limit values for $\mathrm{Cu}, \mathrm{Zn}$, $\mathrm{Pb}, \mathrm{Cd}, \mathrm{Fe}, \mathrm{Ni}$ and $\mathrm{Al}$ were 1.2, 1.8, 40.0, 2.0, 1.3, 6.5 and $2.0 \mu \mathrm{g} \mathrm{g}^{-1}$, respectively. The recovery percentages of metals in the samples were determined between 86.49 and $114.0 \%$ according to the standard reference data (ERMC278, muscle tissue). The blank specimen and samples taken from fish were analysed in three replicates by the same method.

\section{Maximum Permissible Levels and Metal Pollution Index (MPI)}

The concentrations of trace metals detected in four different fishes were evaluated one by one with the maximum permissible element values in fish determined according to national and international food standards (FAO/WHO, 1984/1989; USFDA, 1993; WHO, 1995; TFC, 2002; EC, 2006). The metal absorption of each fish was interpreted with the Metal Pollution Index (MPI) calculated by the equation shown below (Usero et al., 1997): where Cn are the average concentration of trace metals (n) in fish muscle tissue (mgkg ${ }^{1}$ dry weight) used in the study. If this combined index is above 1 the concentrations of trace metals would be considered elevated and ecosystem could be regarded as "polluted" (Teodorovic et al., 2000).

$$
\mathrm{MPI}=(\mathrm{C} 1 \times \mathrm{C} 2 \times \ldots \times \mathrm{Cn})^{1 / \mathrm{n}}
$$

\section{Human Risk Assessment Analysis and Estimated Daily Intake (EDI)}

The estimated weekly intake was determined by calculating the respective levels situated in fish muscle given that the rate of consumption in Turkey in 2015 was 8600 g/person/year, equivalent to $23.56 \mathrm{~g} /$ person/day (TUIK, 2015). Estimated Daily Intake (EDI) values were determined by multiplying the average concentrations of each metal and the quantity of fish consumed daily. The established EDI and Provisional Tolerable Weekly Intake (PTWI) values for a 70 $\mathrm{kg}$ adult were calculated. The EDI was determined using the following equation (Vu et al., 2017).

$$
\mathrm{EDI}=(\mathrm{C} \times \mathrm{FIR}) / \mathrm{B}_{\mathrm{W}}
$$

Where;

$\mathrm{C}=$ Element concentration in fish tissue $\left(\mathrm{mg} \mathrm{kg}^{-1}\right)$

FIR = Fish consumption rate $(23.56 \mathrm{~kg} /$ daily $)$

$\mathrm{BW}=$ Body weight $(70 \mathrm{~kg}$ for adults $)$.

To assess public health risks, the EDI and PTWI intakes (mg kg- ${ }^{1}$ ) were Compared with the PTWI recommended by the Joint FAO/WHO Expert Committee of Food Additives (2004; 2007; 2010), Nasreddin et al. (2010) and EFSA (2011).

\section{Target Hazard Quotients (THQ), Total Target Hazard Quotient (TTHQ) and Target Cancer Risk (TR)}

The health risks for the Turkish consumer from consuming $T$. trachurus, E. encrasicolus, M. merlangus and $M$. barbatus from the Black Sea were detected based on the target hazard quotients (THQ). To determine the risk to human health from consuming fish contaminated with trace metals, the THQ is calculated according to the Region III Risk-Based Concentration Table of the United States Environmental Protection Agency (USEPA, 2018). This method is an indicator of the non-carcinogenic risk level from exposure to trace metals. To calculate THQ, the equation shown below was taken into consideration (Han et al.,1998; Chien et al., 2002; Storelli, 2008):

$$
\begin{aligned}
\mathrm{THO} & =\frac{\left(\mathrm{E}_{\mathrm{F}} \times \mathrm{E}_{\mathrm{D}} \times \mathrm{F}_{\mathrm{IR}} \times \mathrm{C}\right)}{\left(\mathrm{RfD}_{\mathrm{o}} \times \mathrm{W}_{\mathrm{ab}} \times \mathrm{T}_{\mathrm{a}}\right)} \times 10^{-3} \\
\mathrm{TTHQ} & =\mathrm{THQ} 1+\mathrm{THQ} 2+\ldots \mathrm{THQn}
\end{aligned}
$$

According to Bannett et al. (1999), $\mathrm{E}_{\mathrm{F}}$ is the exposure frequency ( 365 days/year), the duration of exposure $\left(E_{D}\right)$ is the mean lifetime (70 years). The food ingestion rate $\left(\mathrm{F}_{\mathrm{IR}}\right)$ 
for Turkish consumers is $23.56 \mathrm{~g} / \mathrm{day}$ (TUIK 2015). Kumar et al. (2013) determined that $\mathrm{C}$ is the metal concentration $\left(\mathrm{mg} \mathrm{kg}^{-1}\right), \mathrm{RfD}_{\mathrm{o}}$ is the oral reference dose $\left(\mathrm{mg} \mathrm{kg}^{-1} \mathrm{day}^{-1}\right)$, $\mathrm{W}_{\mathrm{ab}}$ is the average body weight $(70 \mathrm{~kg})$ and $\mathrm{T}_{\mathrm{a}}$ is the average exposure time for noncarcinogens (365 days/year $\times$ ED, supposing 70 years in this work). The oral reference doses $\left(\mathrm{RfD}_{\mathrm{o}}\right)$ for $\mathrm{Cu}, \mathrm{Zn}, \mathrm{Pb}, \mathrm{Cd}, \mathrm{Fe}, \mathrm{Ni}$ and $\mathrm{Al}$ have been suggested as 0.04, 0.30, 0.002, 0.001, 0.70, 0.02 and 1.00 $\left(\mathrm{mg} \mathrm{kg-}{ }^{1} \mathrm{day}^{-1}\right.$ ) respectively (FAO/WHO: 2004, 2007, 2010; Nasreddine et al., 2010; EFSA, 2011; USEPA, 2018). The total THQ (TTHQ) was determined as the sum of the THQ of the trace metal in each fish. To appreciate the total potential health risk posed by more than one fish, the THQ values of every fish areadded up and this becomes the hazard index $(\mathrm{HI})$. For detecting the total potential health risk of more than one metal, the TTHQ may be calculated as the aggregate of the THQs of each element (USEPA, 2018). The hazard index (HI) to the human population owing to exposure to trace metals $(\mathrm{Cu}, \mathrm{Zn}, \mathrm{Pb}$, $\mathrm{Cd}, \mathrm{Fe}, \mathrm{Ni}$ and $\mathrm{Al}$ ) exposure throughfish consumptionwas calculated as follows (Zheng et al., 2007; Ahmed et al., 2016; Javed and Usmani, 2016; Mol et al., 2017):

$$
\begin{gathered}
\mathrm{HI}=\mathrm{TTHQ}_{\mathrm{Cd}}+\mathrm{TTHQ}_{\mathrm{Cu}}+\mathrm{TTHQ}_{\mathrm{Pb}}+\mathrm{TTHQ}_{\mathrm{Ni}}+ \\
\mathrm{TTHQ}_{\mathrm{Zn}}+\mathrm{TTHQ}_{\mathrm{Fe}}+\mathrm{TTHQ}_{\mathrm{Al}}
\end{gathered}
$$

Target cancer risk (TR) is used to demonstrate the carcinogenic risk. Risk evaluations are based upon suppositions. The method used to assess TR is given inthe USEPA Region III Risk-Based Concentration Table (USEPA, 2018). TR was calculated by the following equation:

$$
\mathrm{TR}=\frac{\left(\mathrm{E}_{\mathrm{F}} \times \mathrm{E}_{\mathrm{D}} \times \mathrm{F}_{\mathrm{IR}} \times \mathrm{C} \times \mathrm{CPS}_{\mathrm{o}}\right)}{\left(\mathrm{W}_{\mathrm{ab}} \times \mathrm{T}_{\mathrm{C}}\right)} \times 10^{-3}
$$

$E_{F}, E_{D}, F_{I R}, C$ and $W_{a b}$ are described in the above mentioned THO equation. CPSo is the carcinogenic potencyslope, oral $\left(\mathrm{mg} \mathrm{kg}^{-1} \mathrm{bw}^{-1} \mathrm{day}^{-1}\right)$. Tc is the average time for carcinogens (365 days/year $\times 70$ years). The CPSo table values of $\mathrm{Cu}, \mathrm{Zn}, \mathrm{Cd}, \mathrm{Fe}$ and $\mathrm{Al}$ have not yet been disclosed by USEPA. That's why their carcinogenic effects have not been calculated. Since CPSo values for $\mathrm{Ni}$ and $\mathrm{Pb}$ were known, and TR values were determined when these elements were taken. Their CPSo values are the slope calculated as constant by USEPA (2018) and this is shown in Table 5.

\section{Statistical Analysis of Data}

Minitab 16.0 statistical package program was used to analyze the results obtained statistically. The suitability of the data to normal distribution was tested by AndersonDarling test. Homogeneity of variances between fish species was tested using Levene's statistic test. In cases where the distribution was not normal, nonparametric Kruskal-Wallis test was applied. The significance test of homogenous groups was evaluated with the Tukey-HSD test following the one-way Variance Analysis (ANOVA). It was concluded that the $\mathrm{P}$ results obtained $(\mathrm{P}>0.05)$ were not statistically significant. Correlation matrix analysis was used to determine whether there was a correlation between $\mathrm{Cu}, \mathrm{Zn}$, lead, $\mathrm{Cd}, \mathrm{Fe}, \mathrm{Ni}$ and $\mathrm{Al}$ concentrations obtained from muscle tissue. Statistical significance was given when the correlation values between the metals of the fishes were $\mathrm{P} \leq 0.001, \mathrm{P} \leq 0.01, \mathrm{P} \leq 0.05$ and except for $\mathrm{P}>0.05$.

\section{Results and Discussion}

\section{Concentrations of Trace Metals}

In the study, the body length and weight of each of the 806 fish were determined. The mean values and standard deviation of weight and length measurements were $29.13 \pm 1.11 \mathrm{~g}$ and $13.30 \pm 0.18 \mathrm{~cm}$ (T. trachurus); $10.25 \pm 0.27 \mathrm{~g}$ and $11.17 \pm 0.10$ $\mathrm{cm}$ (E. encrasicolus); $29.62 \pm 1.84 \mathrm{~g}$ and $14.90 \pm 0.30 \mathrm{~cm}(M$. merlangus euxinus); $19.67 \pm 0.87 \mathrm{~g}$ and $11.33 \pm 0.16 \mathrm{~cm}(M$. barbatus). The results of one-way analysis of variance with the metal levels in the muscles of the fish are shown in Table 1. Although each metal concentration $(\mathrm{Cu}, \mathrm{Zn}, \mathrm{Fe}$ and $\mathrm{Al})$ showed statistically significant differences between the four fish samples $(\mathrm{P}<0.05)$, the statistical differences between the concentrations of $\mathrm{Pb}, \mathrm{Cd}$ and $\mathrm{Ni}$ in the same fish were not significant $(\mathrm{P}>0.05)$. The variations that were expressed in the different standard deviations that occurred in individual metals were the results we expected. The results of the Anova test showed the complex relationship between environmental concentrations of metals and bioaccumulation in fish. Trace metals of industrial activities or anthropogenic origin may cause contamination of fish muscle in water. Environmental and anthropogenic sources are responsible for the different amounts of bioaccumulation of these metals (Jovic et al., 2012). According to Cai et al. (2017) the most likely reason for the different amounts may be related to the fish having different capacities to accumulate metals, as much as how much the water environment has been affected by its environment in previous years (Mutlu et al., 2012). The sequential order of the levels of the trace metals achieved from the muscle tissues of four different fish were $\mathrm{Zn}>\mathrm{Fe}$ $>\mathrm{Al}>\mathrm{Cu}>\mathrm{Ni}>\mathrm{Pb}>\mathrm{Cd}$. The results showed that the mean concentrations were higher for $\mathrm{Zn}(25.06 \mathrm{mg} / \mathrm{kg})$ and $\mathrm{Fe}$ (23.06 mg/kg). The higher concentrations of these metals were not surprising, owing to fact that they are essential elements in fish nutrition. Mol et al. (2017) found similar values of $\mathrm{Zn}$ concentration in red mullet. Similar trace metal results were seen in study Jezierska and Witeska (2006) and Javed and Usman (2011).

In many studies on this subject, it has been shown that the amount of trace metal in the muscle of fish varies according to the fish species and there is a statistically significant correlation (Mohammadnabizadeh et al., 2013; Monroy et al., 2014). While T. trachurus and E. encrasicolus are the pelagic species used in this study, $M$. merlangus euxinus and $M$. barbatus are benthic fish species. The maximum levels of metal accumulation in each species were identified in $M$. barbatus for $\mathrm{Pb}$ and $\mathrm{Cd}$; in $M$. merlangus euxinus for $\mathrm{Cu}$ and $\mathrm{Al}$; in $E$ .encrasicolus for $\mathrm{Zn}, \mathrm{Fe}$ and $\mathrm{Ni}$. When the maximum values of the metals were compared, it is determined that the level of metals was higher in the benthic fish than in the pelagic fish (Yi et al., 2011; Hosseini et al., 2015). The degree of absorption of metals by fish depends on the depth of the body of water in which they live, as well as on the species of fish. Sediment at the base of the aquatic system is very dense in terms of heavy metal content (Dalman et al., 2006; Liu et al., 2015). The MPI was calculated to compare the total metal concentrations in 
the muscles of four different fish species (Table 1). The following order was seen: E. encrasicolus (1.75) $>M$. merlangus euxinus $(1.65)>M$. barbatus (1.63) $>T$. trachurus (1.46). According to the data obtained from the study, the metal absorption of benthic fish is higher than other fish species, which is related to the amount of metal and the form of metal (ion, compound, dissolved etc.) presence in water. Besides, the amount of MPI determined in fish muscles is significantly associated with fish species has indicated in research (Li et al., 2013; Idris et al., 2015; Cai et al., 2017).

Table 1. Trace metal concentrations determined in muscle tissues of fish samples ( $\left.\mu \mathrm{g} \mathrm{g}^{-1} \mathrm{dry}_{\text {weight; }} X \pm s x\right)$

\begin{tabular}{|c|c|c|c|c|c|c|c|c|c|}
\hline Species & $\mathrm{N}$ & MPI & $\begin{array}{c}\mathrm{Cu} \\
\text { Min-max }\end{array}$ & $\begin{array}{c}\text { Zn } \\
\text { Min-max }\end{array}$ & $\begin{array}{c}\mathrm{Pb} \\
\text { Min-max }\end{array}$ & $\begin{array}{c}\mathrm{Cd} \\
\text { Min-max }\end{array}$ & $\begin{array}{c}\text { Fe } \\
\text { Min-max }\end{array}$ & $\begin{array}{c}\mathrm{Ni} \\
\text { Min-max }\end{array}$ & $\begin{array}{c}\mathrm{Al} \\
\text { Min-max }\end{array}$ \\
\hline T. trachurus & 162 & 1.46 & $\begin{array}{c}0.66 \pm 0.02^{\mathrm{a}} \\
0.63-0.70\end{array}$ & $\begin{array}{l}25.63 \pm 1.43^{b} \\
20.48-35.03\end{array}$ & $\begin{array}{c}0.32 \pm 0.03^{\mathrm{a}} \\
0.05-0.70\end{array}$ & $\begin{array}{c}0.17 \pm 0.06^{\mathrm{a}} \\
0.09-0.29\end{array}$ & $\begin{array}{l}19.47 \pm 0.36^{\mathrm{a}} \\
15.32-21.15\end{array}$ & $\begin{array}{c}0.74 \pm 0.05^{\mathrm{a}} \\
0.66-0.96\end{array}$ & $\begin{array}{c}1.07 \pm 0.05^{\mathrm{a}} \\
0.91-1.05\end{array}$ \\
\hline E. encrasicolus & 296 & 1.75 & $\begin{array}{c}1.09 \pm 0.06^{\mathrm{b}} \\
0.75-1.53\end{array}$ & $\begin{array}{c}36.6 \pm 1.85^{\mathrm{c}} \\
28.05-48.68\end{array}$ & $\begin{array}{c}0.30 \pm 0.02^{\mathrm{a}} \\
0.05-0.59\end{array}$ & $\begin{array}{c}0.15 \pm 0.02^{\mathrm{a}} \\
0.05-0.19\end{array}$ & $\begin{array}{l}28.30 \pm 0.79^{b} \\
24.42-34.43\end{array}$ & $\begin{array}{c}0.87 \pm 0.03^{\mathrm{a}} \\
0.64-1.52\end{array}$ & $\begin{array}{c}1.12 \pm 0.03^{\mathrm{a}} \\
1.02-1.49\end{array}$ \\
\hline M. merlangus euxinus & 186 & 1.65 & $\begin{array}{c}1.39 \pm 0.09^{\mathrm{b}} \\
0.98-1.59\end{array}$ & $\begin{array}{l}25.09 \pm 1.79^{b} \\
18.64-30.43\end{array}$ & $\begin{array}{c}0.18 \pm 0.02^{\mathrm{a}} \\
0.02-0.41\end{array}$ & $\begin{array}{c}0.15 \pm 0.04^{\mathrm{a}} \\
0.08-0.24\end{array}$ & $\begin{array}{l}21.50 \pm 1.73^{a} \\
18.22-31.23\end{array}$ & $\begin{array}{c}0.70 \pm 0.03^{\mathrm{a}} \\
0.56-0.78\end{array}$ & $\begin{array}{c}2.33 \pm 0.13^{\mathrm{b}} \\
1.47-4.15\end{array}$ \\
\hline M.barbatus & 162 & 1.63 & $\begin{array}{c}0.92 \pm 0.06^{\mathrm{ab}} \\
0.77-1.24\end{array}$ & $\begin{array}{l}12.93 \pm 0.59^{a} \\
10.71-14.54\end{array}$ & $\begin{array}{c}0.44 \pm 0.04^{\mathrm{a}} \\
0.14-0.82\end{array}$ & $\begin{array}{c}0.19 \pm 0.03^{\mathrm{a}} \\
0.06-0.29\end{array}$ & $\begin{array}{l}25.12 \pm 1.24^{\mathrm{a}} \\
20.25-39.94\end{array}$ & $\begin{array}{c}0.76 \pm 0.01^{\mathrm{a}} \\
0.61-0.88\end{array}$ & $\begin{array}{c}1.62 \pm 0.10^{\mathrm{ab}} \\
1.14-2.80\end{array}$ \\
\hline
\end{tabular}

a,b,c, Different letters in the same column show statistical differences $(\mathrm{P}<0.05), \mathrm{N}:$ Number of fish, MPI: Metal Pollution Index

The correlation coefficients of the metals are shown in Table 2. Although the correlation between $\mathrm{Al}$ and Fe was positive, the relationship between aluminum and other metals $(\mathrm{Cd}, \mathrm{Ni}, \mathrm{Pb}$ and $\mathrm{Zn})$ were negative. However, these relationships were not statistically significant when compared with $\mathrm{P}>0.05$. While Cd's relationship with both $\mathrm{Pb}$ and $\mathrm{Ni}$ was positive, the relationship between $\mathrm{Cd}$ and other metals $(\mathrm{Cu}, \mathrm{Fe}, \mathrm{Zn})$ were negative and not statistically significant $(\mathrm{P}>0.05)$. The correlation between $\mathrm{Cu}$ and both $\mathrm{Fe}$ and $\mathrm{Zn}$ was both positive and statistically significant $(\mathrm{P} \leq 0.05)$. Fe was also associated strongly and positively with $\mathrm{Ni}$ $(\mathrm{r}=0.363)$ and $\mathrm{Zn}(\mathrm{r}=0.387)$ at $\mathrm{P} \leq 0.001$. There was a negative correlation between $\mathrm{Pb}$ and $\mathrm{Zn}(\mathrm{r}=0.220)$ at $\mathrm{P} \leq 0.05$. Uluturhan and Kücüksezgin (2007) and Gundogdu et al. (2016) thought that there was a powerful positive correlation of $\mathrm{Zn}$ with $\mathrm{Cu}$ and $\mathrm{Cd}$ on account of the fact that these trace metal arrive from the identical resources. The interplays and similar accumulation behavior of elements in fish may be described by the positive correlation between the different metals identified in their muscle tissues. (Kojadinovic et al.,2007). Metal density in water column is several times lower than sediments (Mendil and Uluozlu, 2007). Trace metal may accumulate on the surface of the sediment. However, they may be dissolved and transferred to the water column due to the water movements and solvent effect of the water. $M$. barbatus is a ground-fish and is in close communicate with the sediment. Therefore, it has more trace metal accumulation than other fish (Tabinda et al., 2013).

Table 2. Correlations between trace metal contents in muscle tissues in four fish

\begin{tabular}{l|cccccc}
\hline & $\mathrm{Al}$ & $\mathrm{Cd}$ & $\mathrm{Cu}$ & $\mathrm{Fe}$ & $\mathrm{Ni}$ & $\mathrm{Pb}$ \\
\hline $\mathrm{Cd}$ & -0.119 & & & & \\
$\mathrm{Cu}$ & $0.385^{* * *}$ & -0.222 & & & \\
$\mathrm{Fe}$ & 0.196 & -0.054 & $0.245^{*}$ & & \\
$\mathrm{Ni}$ & -0.169 & 0.117 & -0.010 & $0.363 * * *$ & & \\
$\mathrm{~Pb}$ & -0.102 & 0.179 & $-0.289 * *$ & 0.151 & -0.125 & $-0.220 *$ \\
$\mathrm{Zn}$ & -0.114 & -0.053 & $0.228^{*}$ & $0.387 * * *$ & $0.327 * *$ & - \\
\hline $\mathrm{P}>0.05, * \mathrm{P} \leq 0.05, * * \mathrm{P} \leq 0.01, * * * \mathrm{P} \leq 0.001$ & & & &
\end{tabular}

\section{Risk Assessment of Human Health}

The trace metal results obtained in the study were compared with the consumable limit levels of the different organizations mentioned in Table 3. The maximum $\mathrm{Cu}$ levels permitted for fish are 10, 20 and 30 $\mathrm{mg} \mathrm{kg}^{-1}$ according to the FAO /WHO (1989), TFC (2002) and EC (2006) limits, respectively. $\mathrm{Cu}$ values were found to be lower than the literature values. The highest concentration of $\mathrm{Zn}$ was measured at $48.68 \mu \mathrm{g} \mathrm{g}^{-1}$ in $E$. encrasicolus. This concentration was above the FAO (1983) and FAO/WHO (1989) limits, but the legal limit of the TFC was below $50 \mu \mathrm{g} \mathrm{g}^{-1}$ (TFC, 2002). Pb was detected in almost all the samples and the highest concentration $\left(0.82 \mu \mathrm{g} \mathrm{g}^{-1}\right)$ was detected in M. barbatus; however, the value was below the limits of $1.5 \mu \mathrm{g} \mathrm{g}^{-1}$ (EC, 2006). When the results of the study are compared with the standard limit values, it is clear that $\mathrm{Cd}$ in all species studied except E. encrasicolus was above the TFC (2002 and EC (2006) limits, and that $\mathrm{Pb}$ was below the FAO (1983), FAO/WHO (1989) and EC (2006) limits. The highest concentration of Fe was measured as $39.94 \mu \mathrm{g} \mathrm{g}^{-1}$ in $M$. barbatus, whereas the highest Fe concentration of average values was $28.30 \pm 0.79 \mu \mathrm{g} \mathrm{g}^{-1}$ in E.encrasicolus. This concentration was well below the legal limit of 80 $\mu \mathrm{g} \mathrm{g}^{-1}$ and $100 \mu \mathrm{g} \mathrm{g}^{-1}$ (FAO/WHO, 1984; 1989). Ni was detected in all fish samples analyzed in a range of $0.56-$ $0.88 \mu \mathrm{g} \mathrm{g}^{-1}$ dry weight. The highest concentration was 
detected in M. barbatus. Ni values in all of the fish were very under the legal limit of $80 \mu \mathrm{g} \mathrm{g}^{-1}$ (USFDA, 1993). In the study, the highest aluminum concentration was determined in $M$. merlangus euxinus (4.15 $\mu \mathrm{g} \mathrm{g}^{-1)}$. Comparison could not be made since there is no limit value for $\mathrm{Al}$.

\section{Dietary Intake of Trace Metals}

The daily and weekly intake of metals in Sinop was calculated from the consumption of seafood by an adult individual (Table 4). In this study, all trace metal intake through fish consumption in Sinop was determined to be below the daily and weekly intake limits. Similarly, in studies carried out by Turkmen and Dura (2016) and Mol et al. (2017) indicated that EWI and EDI values of red mullets caught in the Black Sea were below the consumable limit. Bat and Aric1 (2016) explained that the trace metal ratios of the Atlantic acorn captured in the Black Sea were below the specified PTWI values.

Table 3. Comparison of trace metal concentrations and international standards in fish $\left(\mu \mathrm{g} \mathrm{g}^{-1}\right)$.

\begin{tabular}{l|cccccccl}
\hline \multicolumn{1}{c}{ Organization } & $\mathrm{Cu}$ & $\mathrm{Zn}$ & $\mathrm{Pb}$ & $\mathrm{Cd}$ & $\mathrm{Fe}$ & $\mathrm{Ni}$ & $\mathrm{Al}$ & \multicolumn{1}{c}{ Reference } \\
\hline FAO & 30 & 30 & $0.5-2$ & 0.5 & - & - & - & FAO (1983) \\
EC & - & - & 1.5 & 0.05 & - & - & - & EC (2006) \\
WHO & 30 & - & 2 & - & - & - & - & WHO (1995) \\
USFDA & - & - & - & - & - & $70-80$ & - & USFDA (1993) \\
FAO/WHO & 30 & 40 & 0.5 & 0.5 & 100 & - & - & FAO/WHO (1989) \\
FAO/WHO & 30 & 50 & - & 2 & 80 & - & - & FAO/WHO (1984) \\
Turkish & 20 & 50 & 0.30 & $0.05-0.1$ & - & - & - & TFC (2002) \\
\hline
\end{tabular}

FAO: Food and Agriculture Organization, EC: European Commission, WHO: World Health Organization, USFDA: Food and drug administration (US), TFC: Turkish food codex.

Table 4. The estimated daily (EDI) and weekly (PTWI) intakes (mg/kg) for T. trachurus, E. encrasicolus, M. merlangus euxinus and M. barbatus from Black Sea, consumed by adult people in Sinop.

\begin{tabular}{|c|c|c|c|c|c|c|c|c|c|c|}
\hline \multirow[t]{2}{*}{ Heavy Metals } & \multirow[t]{2}{*}{ EDI } & \multirow[t]{2}{*}{ PTWI } & \multicolumn{2}{|c|}{ T. trachurus } & \multicolumn{2}{|c|}{ E. encrasicolus } & \multicolumn{2}{|c|}{$\begin{array}{l}\text { M. merlangus } \\
\text { euxinus }\end{array}$} & \multicolumn{2}{|c|}{ M. barbatus } \\
\hline & & & EDI* & PTWI* & EDI* & PTWI* & EDI* & PTWI* & EDI* & PTWI* \\
\hline $\mathrm{Cd}^{\mathrm{a}}$ & 0.0575 & 0.403 & 0.057 & 0.399 & 0.05 & 0.35 & 0.05 & 0.35 & 0.064 & 0.448 \\
\hline $\mathrm{Cu}^{\mathrm{b}}$ & 35 & 245 & 0.222 & 1.554 & 0.367 & 2.569 & 0.468 & 3.276 & 0.31 & 2.17 \\
\hline $\mathrm{Pb}^{\mathrm{c}}$ & 0.25 & 1.75 & 0.108 & 0.756 & 0.101 & 0.707 & 0.061 & 0.427 & 0.148 & 1.036 \\
\hline $\mathrm{Ni}^{\mathrm{e}}$ & 0.35 & 2.45 & 0.249 & 1.743 & 0.293 & 2.051 & 0.236 & 1.652 & 0.256 & 1.792 \\
\hline $\mathrm{Zn}^{\mathrm{b}}$ & 70 & 490 & 8.626 & 60.382 & 12.319 & 86.233 & 8.445 & 59.115 & 4.352 & 30.464 \\
\hline $\mathrm{Fe}^{\mathrm{b}}$ & 56 & 392 & 6.553 & 45.871 & 9.525 & 66.675 & 7.236 & 50.652 & 8.455 & 59.185 \\
\hline $\mathrm{Al}^{\mathrm{d}}$ & 20 & 140 & 0.36 & 2.52 & 0.77 & 5.39 & 0.784 & 5.488 & 0.545 & 3.815 \\
\hline
\end{tabular}

PTWI:The established provisional tolerable weekly intake (mg/week/kg body weight); EDI: The estimated provisional tolerable daily Intake (mg/daily body weight); PTWI*: Weekly intake values calculated for a $70 \mathrm{~kg}$ adult (mg/week body weight) EDI*: Daily intake values calculated for an adult of $70 \mathrm{~kg}$ (mg/daily body weight); ${ }^{\mathrm{a}} \mathrm{FAO} / \mathrm{WHO}$ (2010); ${ }^{\mathrm{b}} \mathrm{FAO} / \mathrm{WHO}$ (2007); ${ }^{\mathrm{c}} \mathrm{FAO} / \mathrm{WHO}$ (2004); ${ }^{\mathrm{d}} \mathrm{EFSA}$ (2011); ${ }^{\mathrm{e}}$ Nasreddin et al. (2010)

\section{Potency Healthiness Hazard, THQ, HI and TR}

Trace elements being able to cause carcinogenic and mutagenic effects in humans over time (Goyer et al., 2003). The International Cancer Research Agency (IARC 2014) reported that it belongs to a group in the $\mathrm{Ni}, \mathrm{Cd}$ and $\mathrm{Pb}$ classification systems and has sufficient evidence of carcinogenic effects on humans. The THQ has been recognized as a useful parameter for the assessment of health risk associated with the consumption of heavy metalcontaminated food (Jezierska and Witeska, 2006; Abdallah, 2013). The admissible guideline value for THQ is 1 (USEPA, 2011). THQ values $<1$ thus demonstrate that exposure is not as a potential concern. As displayed in Table 5, there were no THQ values for any of the metals greater than 1 , suggesting that the local people are be exposed not to a potential health risk from $\mathrm{Cu}, \mathrm{Zn}, \mathrm{Pb}, \mathrm{Cd}, \mathrm{Fe} \mathrm{Ni}$ and $\mathrm{Al}$ in fish. Turk Culha et al. (2016) studied the potential human health risks of scorpionfish species caught from the Black Sea and also reported THQ values for trace metals ( $\mathrm{Al}, \mathrm{Cd}, \mathrm{Hg}, \mathrm{As}, \mathrm{Pb}, \mathrm{Cu}$, $\mathrm{Ni}, \mathrm{U})$ of below 1 and that there was thus no threat to humans from consumption of scorpionfish. When we look at the results of TTHQs (Table 5), it is determined that fish consumption does not pose a risk for human health due to 1>HI. Mol et al. (2017) reported that the THQ and HI (sum of
TTHQ or TDHQ) values were below 1 and that consumption of fish species from the southwest Black Sea might not be hazardous to the consumer with respect to the observed levels of $\mathrm{Hg}, \mathrm{Cu}, \mathrm{Pb}, \mathrm{Zn}$ and $\mathrm{Cd}$ alone or in combination with each other. Moslen and Miebaka (2017) found that in the Sarotherodon melanotheron species exemplified in Nigeria Creek, $\mathrm{HI}$ values were $<1$ for $\mathrm{Ni}, \mathrm{Cu}, \mathrm{Pb}$ and $\mathrm{Cd}$.

TR values were calculated to determine whether there is a carcinogenic hazard. The TR were not calculated because the CPSo table values for $\mathrm{Cd}, \mathrm{Cu}, \mathrm{Zn}$, $\mathrm{Fe}$ and $\mathrm{Al}$ were unknown. As CPSo values of $\mathrm{Ni}$ and Pbare known, the TR values were calculated by considering these metals together with the diet (Table 6). Although the TR values of $\mathrm{Pb}$ were smaller than the limit values specified as a carcinogenic value, $\mathrm{Ni}$ concentration waspretty close to the limit value. Since TR values were higher than the admissible limit of $10^{-6}$, it shows that over-consumption of fish a long period of time may result carcinogenic effects (USEPA 2018).It has been explained by many researchers that the $\mathrm{Pb}$ from the consumption of the fish does not carry the risk of cancer, but that $\mathrm{Ni}$ does pose a risk of cancer (Ahmed et al., 2015; Islam et al., 2015; Javed and Usmani, 2016; 
Ahmed et al., 2016). TR values lower than $10^{-6}$ are noted to show a negligible carcinogenic risk; cancer risks above $10^{-4}$ are noted to be unacceptable (USEPA 1989, 2010), and risks lying between $10^{-6}$ and $10^{-4}$ are generally noted to be in an acceptable range (Fryer et al. 2006). The TR values for $\mathrm{Ni}$ in all the fish were higher than the admissible limits of $10^{-6}-10^{-4}$ founded by USEPA (2018), pointing to a potency healthiness hazard for people consuming the fish. This suggests that the levels of $\mathrm{Pb}$ in fish from the Black Sea are safe for human consumption and there may only be a risk of cancer in terms of $\mathrm{Ni}$ taken in as a result of continuous and excessive fish consumption. Similar results for $\mathrm{Ni}$ have been reported by Bhupander and Mukherjee (2011) and Ahmed et al., 2016).

Table 5. The Estimated Target Hazard Quotients (THQ) for metals caused by consuming T. trachurus, E. encrasicolus, $M$. merlangus euxinus and M. barbatus from the Black Sea

\begin{tabular}{|c|c|c|c|c|c|}
\hline \multirow{2}{*}{ Heavy Metals } & T. trachurus & E. encrasicolus & M. merlangus euxinus & M. barbatus & $\mathrm{HI}$ \\
\hline & THQ<1 & THQ $<1$ & THQ $<1$ & THQ<1 & $\mathrm{HI}$ \\
\hline $\mathrm{Cd}^{\mathrm{a}}$ & 0.057 & 0.050 & 0.050 & 0.064 & \multirow{8}{*}{0.676} \\
\hline $\mathrm{Cu}^{\mathrm{b}}$ & 0.006 & 0.009 & 0.012 & 0.008 & \\
\hline $\mathrm{Pb}^{\mathrm{c}}$ & 0.054 & 0.050 & 0.030 & 0.074 & \\
\hline $\mathrm{Ni}^{\mathrm{e}}$ & 0.012 & 0.015 & 0.012 & 0.013 & \\
\hline $\mathrm{Zn}^{\mathrm{b}}$ & 0.029 & 0.041 & 0.028 & 0.015 & \\
\hline $\mathrm{Fe}^{\mathrm{b}}$ & 0.009 & 0.014 & 0.010 & 0.012 & \\
\hline $\mathrm{Al}^{\mathrm{d}}$ & 0.00036 & 0.00038 & 0.00078 & 0.00055 & \\
\hline TTHQ & 0.167 & 0.179 & 0.143 & 0.187 & \\
\hline
\end{tabular}

Table 6. Target Cancer Risk (TR) of trace metals from consumption of four fish species collected from Black Sea, Turkey

\begin{tabular}{l|ccccc|}
\hline \multicolumn{5}{c|}{ Target cancer risk (TR) } \\
\hline \multicolumn{1}{c}{ Heavy metals } & CPSo & T. trachurus & E. encrasicolus & $\begin{array}{c}\text { M. merlangus } \\
\text { euxinus }\end{array}$ & M. barbatus \\
\hline $\mathrm{Pb}$ & 0.0085 & $9.0010^{-7}$ & $9.0010^{-7}$ & $5.0010^{-7}$ & $1.3010^{-6}$ \\
$\mathrm{Ni}$ & 1.7 & $4.2310^{-4}$ & $4.9910^{-4}$ & $4.0110^{-4}$ & $4.3510^{-4}$ \\
\hline
\end{tabular}

(CPSo: $\mathrm{mg} \mathrm{kg}^{-1}$ bw-day $\left.^{-1}\right)$

\section{Conclusion}

Fish, as well as being a source of protein, they also serve as a source of rich polyunsaturated fatty acids and are therefore strongly suggested in diets. In addition to their great health benefits, fish are significant in determining and monitoring the levels of trace elements that may come from the sea as a test animal. Therefore, in the Black Sea region, trace metal values of four fish consumed were evaluated. Zinc, lead and cadmium concentrations were determined to be slightly higher than the acceptable values in fish samples. Cd concentration in all studied except anchovy species was above the TFC (2002) and EC (2006) limits, $\mathrm{Pb}$ concentration was below FAO (1983), FAO/WHO (1989) and EC (2006) limits, and Zn concentration was above the FAO (1983) and FAO/WHO (1989) limits. However, the estimated daily (EDI) and weekly (PTWI) intake values for $\mathrm{Ni}$ were calculated to be lower than the values given in the USEPA Table. THQ, TTHQ and HI values also remained below 1 , pointing no health risk owing to the intake of individual trace metal by consuming one of T. trachurus, E. encrasicolus, M. merlangus and $M$. barbatus. According to the data obtained at the end of the study, trace metals present either individually or togetherdo not pose a health hazard. Moreover, the combined effect of the four fish was determined not to be harmful to human health, since the HI was less than 1 . In this study, the TR values of $\mathrm{Ni}$ calculated in fish were greater than $10^{-4}$, whereas the TR values of $\mathrm{Pb}$ were smaller than $10^{-6}$. These results suggest that there is no risk of cancer from $\mathrm{Pb}$, although there is a high carcinogenic risk for consumption of $\mathrm{Ni}$. Nevertheless, $\mathrm{HI}$, which was the combination value of the trace metals determined in the study, was $<1$ for consumed and evaluated fish, indicating that there was no potential health risk to human health. Health risks may vary depending on consumption amounts for different populations. Therefore, Therefore, the pollutant levels of caught fish from the dense regions of the industry should be identified, and likely health risks should be detected at specific intervals.

\section{References}

Abdallah MAM. 2013. Bioaccumulation of Heavy Metals in Mollusca Species and Assessment of Potential Risks to Human Health. Bull. Environ. Contam. Toxicol. 90:552-557. do1: 10.1007/s00128-013-0959-x

Ahmed MK, Baki MA, Islam MS, Kundu GK, Habibullah-AlMamun M, Sarkar SK, Hossain M.M. 2015. Human health risk assessment of heavy metals in tropical fish and shellfish collected from the river Buriganga, Bangladesh. Environ. Sci. Pollut. R. 22(20): 15880-15890. doi:10.1007/s11356-0154813-z

Ahmed MK, Baki MA, Kundu GK, Islam MS, Islam MM, Hossain MM. 2016. Human health risks from heavy metals in fish of Buriganga river, Bangladesh. Springer Plus. 5: 1697. DOI: $10.1186 / \mathrm{s} 40064-016-3357-0$

Amundsen I. 1997. In Search of a Counter-Force. State Power and Civil Society in the Struggle for Democracy in Africa (Or: Mapping the political landscape of Senegal, the Côte d'Ivoire and Cameroon). PhD thesis, Faculty of Social Science, University of Tromso.

Ateş A, Türkmen M, Tepe Y. 2015. Assessment of Heavy Metals in Fourteen Marine Fish Species of Four Turkish Seas. Indian J. Geo-Mar, Sci., 44 (1): 49-55. 
Bannett DH, Kastenberg WE, McKone TEA. 1999. A multimedia, multiple pathway risk assessment of atrazine: the impact of age differentiated exposure including joint uncertainty and variability. Reliab. Eng. Syst. Safe. 63: 18598. DOI:10.1016/S0951-8320(98)00046-5

Bat L, Arıc1 E. 2016. Health risk assessment of heavy metals in Sarda sarda Bloch, 1793 for people through consumption from the Turkish Black Sea coasts. Int. J. Zool. Res. 1(1): 0107.

Bat L, Arıc1 E, Öztekin A. 2018. Human Health Risk Assessment of Heavy Metals in the Black Sea: Evaluating Mussels. Curr. World Environ. ISSN: 0973-4929, 13(1): 15-31. DOI:10.12944/CWE.13.1.03

Bhupander K, Mukherjee DP. 2011. Assessment of Human Health Risk for Arsenic, Copper, Nickel, Mercury and Zinc in Fish Collected from Tropical Wetlands in India. Advances in Life Science and Technology. ISSN 2224-7181 (Paper) ISSN 2225-062X Online. 2: 13-24.

Cai SW, Ni ZH, Liu B, Fan LL. 2017. Metal Concentrations and Health Risk Assessment in the Muscle of Ten Commercial Fish Species from the Chishui River, China. Int. J. Environ. Res. 11(2): 125-132.

Chien L, Hung T, Choang K, Yeh C, Meng P, Shieh M, Han B. 2002. Daily intake of TBT, Copper, Zinc, Cadmium and As for fishermen in Taiwan. Sci. Total Environ. 285: 177-185. DOI:10.1016/S0048-9697(01)00916-0

Dalman O, Demirak A, Balc1 A. 2006. Determination of heavy metals (Cadmium, Lead) and trace elements (Copper, Zinc) in sediments and fish of the Southeastern Aegean Sea (Turkey) by atomic absorption spectrometry. Food. Chem. 95: 157-162. DOI: 10.1016/j.foodchem.2005.02.009

Duruibe JO, Ogwuegbu MC, Egwurugwu JN. 2007. Heavy metal pollution and human biotoxic effects. Int. J. Phys. Sc1. 2:112118.

EC. 2006. Commission Regulation (EC: European Commission), No 1881/2006 of the European parliament and the council of 19 December setting maximum levels for certain contaminants in foodstuffs. Official Journal of the European Communities, L364/18. https://eur-lex.europa.eu/Lex UriServ/LexUriServ.do?uri=OJ:L:2006:364:0005:0024:EN: PDF

EFSA. 2011. Use of the EFSA comprehensive European food consumption database in exposure assessment. European Food Safety Authority (EFSA) J, 9(3): 2097, 34. DOI 10.2903/j.efsa.2011.2097

FAO. 1983. Compilation of legal limits for hazardous substances in fish and fishery products, FAO (Food and Agriculture Organization) Fishery Circular 464: 5-100.

FAO/WHO. 1984. List of maximum levels recommended for contaminants by the Joint FAO/WHO (Food and Agriculture Organization/World Health Organization). Codex Alimentarius Commission. 3:1-8.

FAO/WHO. 1989. Food and Agriculture Organization/World Health Organization, Evaluation of certain food additives and the contaminants mercury, lead and cadmium, WHO Technical Report, Series No. 505.

FAO/WHO. 2004. Food and Agriculture Organization/World Health Organization, Summary and conclusions of the sixtyfirst meeting of the Joint FAO/WHO expert committee on food additives (JECFA). www.fao.org/3/a-at878e.pdf

FAO/WHO. 2007. Evaluation of certain food additives and contaminants: sixty-seventh report of the Joint FAO/WHO (Food and Agriculture Organization/World Health Organization) Expert Committee on Food Additives. Geneva, World Health Organization (WHO Technical Report Series, No. 940). https://www.who.int/ipcs/publications/jecfa/reports/trs940.pdf

FAO/WHO. 2010. Joint FAO/WHO (Food and Agriculture Organization/World Health Organization) expert committee on food additives. Seventy-third meeting, Geneva, 8-17 June 2010. https://www.who.int/foodsafety/publications/chem/summary73.pdf
Förstner U, Wittmann GTW. 1981. Metal Pollution in the Aquatic Environment. 2nd Edition, Springer-Verlag, Berlin, 486. DOI: 10.1007/978-3-642-69385-4

Fryer M, Collins CD, Ferrier H, Colvile RN, Nieuwenhuijsen MJ. 2006. Human exposure modeling for chemical risk assessment: a review of current approaches and research and policy implications. Environ. Sci. Policy. 9:261-274. DOI: 10.1016/j.envsci.2005.11.011.

Goyer R, Mari G, Harlal C, Micheal H, Elaine K, Marc S. 2003. Issue papper on the Human Health Effects of Metals, U.S. Environmental Protection Agency (EPA) Risk Assessment Forum, 4: 23-28.

Gundogdu A, Culha ST, Kocbas F, Culha M. 2016. Heavy Metal Accummulation in Muscles and Total Bodies of Mullus barbatus, Trachurus trachurus and Engraulis encrasicolus Captured from the Coast of Sinop, Black Sea. Pakistan J. Zool. 48(1): 25-34. DOI: 0030-9923/2016/0001-0025

Han BC, Jeng WL, Jeng MS, Hung TC. 1994. Copper intake and health threat by consuming seafood from copper contaminated coastal environments in Taiwan. Environ Toxicol. Chem. 13(5): 775-780.

Han BC, Jeng WL, Chen, RY, Fang GT, Hung TC, Tseng RJ. 1998. Estimation of target hazard quotients and potential health risks for metals by consumption of seafood in Taiwan. Arch. Environ. Contam. Toxicol. 35: 711- 720. DOI: 10.1007/s002449900535

Han BC, Jeng, WL, Hung TC, Ling YC, Shieh MJ, Chien LC. 2000. Estimation of metal and organochlorine pesticide exposures and potential health threat by consumption of oysters in Taiwan. Environ. Pollut. 109: 147-156. DOI: 10.1016/S0269-7491(99)00236-5

Hosseini SV, Sobhanardakani S, Miandare HK, Harsij M, Regenstein JM. 2015. Determination of toxic (Lead, Cadmium) and essential (Zinc, Mn) metals in canned tuna fish produced in Iran. J. Environ. Health Sci. Eng. 13: 59. DOI: 10.1186/s40201-015-0215-x

Idris AM, Said TO, Omran AA, Fawy KF. 2015. Combining multivariate analysis and human risk indices for assessing heavy metal contents in muscle tissues of commercially fish from Southern Red Sea, Saudi Arabia. Environ. Sci. Pollut. Res. 22 (21): 17012-17021. doi:10.1007/s11356-015-4921-9

Islam MdS, Ahmed MdK, Habibullah-Al-Mamun Md. 2015. Determination of Heavy Metals in Fish and Vegetables in Bangladesh and Health Implications, Hum. Ecol. Risk Assess. (An International Journal) 21(4): 986-1006. DOI: 10.1080/10807039.2014.950172

IARC. 2014. International Agency for Research on Cancer (IARC), World Cancer Report 2014. http://www.iarc.fr/en/publications /books/wcr/wcr-order.php

Javed M, Usmani N. 2011. Accumulation of heavy metals in fishes: a human health concern. Int. J. Environ. Sci. 2: 659670. DOI: $10.6088 /$ ijes.00202020026

Javed M, Usmani N. 2016. Accumulation of heavy metals and human health risk assessment via the consumption of freshwater fish Mastacembelus armatus inhabiting, thermal power plant effluent loaded canal. Javed and Usmani Springer Plus, 5: 776. DOI: 10.1186/s40064-016-2471-3

Jezierska B, Witeska M. 2006. The metal uptake and accumulation in fish living in polluted waters. Soil and water pollution monitoring, protection and remediation. Springer, Netherlands, 107-114.

Jovic M, Onjia A, Stankovic S. 2012. Toxic metal health risk by mussel consumption. Environ. Chem. Lett. 10: 69-77. DOI: 10.1007/s10311-011-0330-6.

Kojadinovic J, Potier M, Le Corre M, Cosson R. Bustamante P. 2007. Bioaccumulation of trace elements in pelagic fish from the Western Indian Ocean. Environ. Pollut. Elsevier, 146 (2): 548-566. DOI: 10.1016/j.envpol.2006.07.015 
Köse E, Uysal K. 2008. The Comparison of Heavy Accumulation Ratios in Muscle, Skin and Gill of Non-Maturated Common Carp (Cyprinus carpio L., 1758) (in Turkish with English abstract). J. Sci. Technol. Dumlupınar University. 17: 19-26

Kromhout D, Bosschieter EB, de Lezenne Coulander C. 1985. The inverse relation between Rsh consumption and 20-year mortality from coronary heart disease. N. Eng. J. Med. 312: 1205-1209.

Kumar B, Verma VK, Naskar AK, Chakraborty P, Shah R. 2013. Human Health Hazard due to Metal Uptake via Fish Consumption from Coastal and Fresh Water Waters in Eastern India Along the Bay of Bengal. J. Mar. Biol. Ocean. 2: 3. DOI:10.4172/23248661.1000115.

Li J, Huang ZY, Hu Y, Yang H. 2013. Potential risk assessment of heavy metals by consuming shellfish collected from Xiamen, China. Environ. Sci. Pollut. Res. 20: 2937-2947. DOI: 10.1007/s11356-012-1207-3.

Liu K, Wu L, Couture RM, Li W, Cappellen PV. 2015. Iron isotope fractionation in sediments of an oligotrophic freshwater lake. Earth. Planet. Sci. Lett. 423: 164-172. DOI:10.1016/j.epsl.2015.05.010

Mendil D, Uluozlu DO. 2007. DetermInatIon of Tracemetal Levels in SedIment and FIve FIsh SpecIes from Lakes in Tokat, Turkey. Food Chem. 101: 739-745 DOI:10.1016/j.foodchem.2006.01.050

Mohammadnabizadeh S, Afshari R, Pourkhabbaz A. 2013. Metal concentrations in marine fishes collected from Hara biosphere in Iran. Bull. Environ. Contam. Toxicol. 90: 188-93 DOI: 10.1007/s00128-012-0876-4

Mok JS, Kwon JY, Son KT, Choi WS, Kim PH, Lee TS. Kim JH. 2015. Distribution of heavy metals in internal organs and tissues of Korean molluscan shellfish and potantial risk to human health. J. Environ. Biol. 36: 1161-1167.

Mol S, Karakulak FS, Ulusoy S. 2017. Assessment of Potential Health Risks of Heavy Metals to the General Public in Turkey via Consumption of Red Mullet, Whiting, Turbot from the Southwest Black Sea. Turk. J. Fish. Aquat. Sc. 17: 1135-1143. DOI 10.4194/1303-2712-v17_6_07

Monroy M, Veiga AM, Sostoa AD. 2014. Metal concentration in water, sediment and four fish species from Lake Titicaca reveals a large-scale environmental concern. Sci. Total Environ. 487:23344. DOI: 10.1016/j.scitotenv.2014.03.134

Moslen M, Miebaka CA. 2017. Concentration of Heavy Metals and Health Risk Assessment of Consumption of Fish (Sarotherodon melanotheron) from an Estuarine Creek in the Niger Delta, Nigeria. IOSR, J. Environ. Sci., Toxicol. Food Technol. 11(3): 6873. DOI: $10.9790 / 2402-1103026873$

Mutlu C, Türkmen A, Türkmen M, Tepe Y, Ateş A. 2012 Comparision of the heavy metal concentrations in Atlantic Horse Mackerel, Trachurus trachurus, from coastal waters of Turkey. Fresen. Environ. Bull. 21 (2): 304-307.

Nasreddine L, Nashalian O, Naja F, Itani L, Parent-Massin D, NabhaniZeidan M, Hwalla N. 2010. Dietary exposure to essential and toxic trace elements from a total diet study in an adult Lebanese urban population. Food Chem. Toxicol. 48: 1262-1269. DOI 10.1016/j.fct.2010.02.020

Sipahi N, Mutlu C, Akkan T. 2013. Giresun İlinde Tüketime Sunulan Bazı Balıklardan İzole Edilen Enterobacteriaceae Üyelerinin Antibiyotik ve Ağır Metal Dirençlilik Düzeyleri. Gıda. 38(6):343349. DOI: 10.5505/gida.2013.55264.

Stankovic S, Jovic M, Stankovic AR, Katsikas L. 2011. Heavy metals in seafood mussels Risk for human health. In: Lichtfouse E, Schwarzbauer J, Robert D (eds) Environmental chemistry, 2. Springer, Netherlands. Chapter 9: 311. DOI: 10.1007/978-94-007-2442-6_9

Stankovic S, Jovic M. 2012. Health risks of heavy metals in the mediterranean mussels as seafood. Environ. Chem. Lett. 10: 119-130. DOI: 10.1007/s10311-011-0343-1.

Storelli MM. 2008. Potential human health risks from metals ( $\mathrm{Hg}$, Cadmium, and Lead) and polychlorinated biphenyls (PCBs) via seafood consumption: Estimation of target hazard quotients (THQs) and toxic equivalents (TEQs). Food Chem. Toxicol. 46(8): 2782-2788. DOI: 10.1016/j.fct.2008.05.011
Svensson BG, Nilsson A, Josson E, Schütz A, Akesson B, Hagmar L. 1995. Fish consumption and exposure to persistent organochlorine compounds, mercury, selenium and methylamines among Swedish fishermen. Scand. J. Work Environ. Health. 21(2): 96-105. DOI:10.5271/sjweh.16

Tabinda AB, Bashir S, Yasar A, Hussain. M. 2013. Metals concentrations in the riverine water, sediments and fishes from river Ravi at Balloki headworks. J. Anim. Plant Sci. 23(1): 76-84. www.thejaps.org.pk/docs/v-23-1/13.pdf

Tepe Y, Türkmen M, Türkmen A. 2008. Assessment of heavy metals in two commercial fish species of four Turkish seas. Environ. Monit. Assess., 146: 277-284.

TFC. 2002. Turkish Food Codex (in Turkish) (Official Gazette of Republic of Turkey). Notifications about determination of the maximum levels for certain contaminants in foodstuffs of Turkish Food Codex (Notification No: 2002/63), 24885. http://www.resmigazete.gov.tr/eskiler/2002/09/20020923.ht $\mathrm{m} \# 5$

Teodorovic I., Djukic N., Maletín S., Miljanovic B. and Jugovac N. 2000. Metal pollution index: proposal for freshwater monitoring based on trace metal accumulation in fish. Tiscia, 32: 55-60.

TUIK. 2015. Turkey Statistical Institute, Fishery Statistics. Ankara, Turkey, Statistical Institute Publications. http://www.tuik.gov.tr/Start.do

TUIK. 2017. Turkey Statistical Institute, Fishery Statistics. Ankara, Turkey, Statistical Institute Publications. http://www.tuik.gov.tr/Start.do

Turk Culha S, Koçbaş F, Gundogdu A, Baki B, Culha M, Topçuoğlu S. 2011. The seasonal distribution of heavy metals in Mussel sample from Yalova in the Marmara Sea, 20082009. Environ. Monit. Assess. 183: 525-529. DOI: 10.1007/s10661-011-1937-6

Turk Culha S, Yabanlı M, Baki B, Yozukmaz A, 2016. Heavy metals in tissues of scorpionfish (Scorpaena porcus) caught from Black Sea (Turkey) and potential risks to human health. Environ. Sci. Pollut. R. DOI:10.1007/s11356-016-7337-2

Türkmen M, Türkmen A, Tepe Y.2008a. Metal Contaminations in Five Fish Species from Black, Marmara, Aegean And Mediterranean Seas", Turkey. J. Chil. Chem. Soc., 53 (1): 1435-1439.

Türkmen, A, Tepe, Y, Türkmen, M. 2008b. Metal levels in tissues of the European Anchovy, Engraulis encrasicolus L., 1758, and Picarel, Spicara smaris L., 1758, from Black, Marmara and Aegean seas. B. Environ. Contam. Tox. 80: 521-525.

Turkmen M, Dura N. 2016. Assessment of heavy metal concentrations in fish from south western Black Sea. Indian J. Mar. Sci. 45 (11): 1552-1559.

Uluturhan E, Kucuksezgin F. 2007. Heavy metal contaminants in Red Pandora (Pagellus erythrinus) tissues from the Eastern Aegean Sea, Turkey. Water Res. 41(6): 1185-1192 DOI:10.1016/j.watres.2006.11.044

USEPA. 1989. Risk assessment guidance for superfund, Vol. I. Human health evaluation. Manual (Part A, Baseline Risk Assessment). Interim Final. Office of Emergency and Remedial Response. EPA/540/1-89/002. https://www.epa.gov/sites/production /files/201509/documents/rags_a.pdf

USEPA. 2010. Risk-based Concentration Table. United State Environmental Protection Agency, Washington, DC.

USEPA. 2011. USEPA regional screening level (RSL) summary table: November 2011. https://www.epa.gov/risk/regionalscreening-levels-rsls-generic-tables-november-2015

USEPA. 2018. Risk-based Concentration Table. Philadelphia PA. Washington DC, USA, Environmental Protection Agency (EPA). Regional Screening Level (RSL) Summary Table (TR=1E-06, HQ=1) November 2018. https://www.epa.gov/risk/regional-screening- levels-rslsgeneric-tables 
Usero J, Gonzalez-Regalado E, Gracia I. 1997. Trace metals in the bivalve molluscs Ruditapes decussatus and Ruditapes philippinarum from the Atlantic Coast of Southern Spain. Environ. Int. 23: 291-298. DOI: 10.1016/S01604120(97)00030-5

USFDA. 1993. Food and drug administration. Guidance document for nickel in shellfish. DHHS/PHS/FDA/CFSAN/Office of Seafood, Washington, DC. https://www.scirp.org/ (S(351jmbntvnsjt1aadkposzje))/reference/ReferencesPapers.asp $\mathrm{x}$ ?ReferenceID $=621255$

Vu CT, Lin C, Yeh G, Villanueva MC. 2017. Bioaccumulation and potential sources of heavy metal contamination in fish species in Taiwan: assessment and possible human health implications, Environ. Sci. Pollut. R. 24(23):19422-19434. DOI:10.1007/s11356-017-9590-4

Who. 1995. World Health Organization, Environmental Health Criteria No 165: Inorganic Lead. Geneva (Switzerland). http://www.inchem.org/documents/ehc/ehc/ehc165.htm
Yap CK, Ismail A, Omar H, Tan SG. 2004. Toxicites and tolerances of Cadmium, Copper, Lead and Zinc in a primary producer (Isochrysis galbana) and in a primary consumer (Perna viridis). Environ. Int. 29: 1097-1104. DOI:10.1016/S01604120(03)00141-7

Yilmaz M, Teber C, Akkan A, Er C, Kariptas E, Ciftci H. 2016. Determination of heavy metal levels in different tissues of tench (Tinca tinca L., 1758) from Siddikli Kucukbogaz dam lake (Kirsehir), Turkey. Fresen. Environ. Bull., 25: 19721977.

Yi Y, Yang Z, Zhang S. 2011. Ecological risk assessment of heavy metals in sediment and human health risk assessment of heavy metals in fishes in the middle and lower reaches of the Yangtze River basin. Environ. Pollut. 159: 2575-2585.

DOI:10.1016/j.envpol.2011.06.011

Zheng N, Wang Q, Zhang X, Zheng D, Zhang Z, Zhang S. 2007. Population health risk due to dieatry intake of heavy metals in the industrial area of Huludao city, China. Sci. Total Environ. 387: 96-104. DOI: 10.1016/j.scitotenv.2007.07.044 